\title{
Spotted fever rickettsiosis in Coronel Fabriciano, Minas Gerais State
}

\author{
Rickettsiose do grupo das febres maculosas na cidade de \\ Coronel Fabriciano, Estado de Minas Gerais
}

\author{
Márcio Antônio Moreira Galvão, ${ }^{1,5}$, Simone Berger Calic², Chequer Buffe Chamone², \\ Cláudio Lísias Mafra S. ${ }^{3}$, Gracco Cesarino Filho ${ }^{4}$, \\ Juan Pablo Olano ${ }^{5}$ and David Hughes Walker ${ }^{5}$
}

\begin{abstract}
We report cases of spotted fever rickettsiosis in Coronel Fabriciano Municipality of Minas Gerais State, Brazil. The cases occurred in May and June of 2000. During this period there were two deaths among children from an area named Pedreira in a periurban area of this municipality. In a boy who died with clinical manifestations of Brazilian spotted fever, a necropsy revealed the presence of a spotted fever group Rickettsia. The serological results confirm the difficulty in the differential diagnosis of patients with symptoms of rickettsial diseases.
\end{abstract}

Key-words: Rickettsiosis. Brazilian spotted fever. Rickettsia rickettsii. Rickettsia typhi. Rickettsia felis.

Resumo São reportados casos de rickettsioses do grupo das febres maculosas no município de Coronel Fabriciano, Estado de Minas Gerais, Brasil. Os casos ocorreram nos meses de maio e junho de 2000. Durante este período, ocorreram dois óbitos em crianças procedentes de uma área peri-urbana conhecida como Pedreira no município de Coronel Fabriciano. Em um menino, que faleceu com manifestações clínicas da febre maculosa brasileira, à necropsia foi revelada a presença de Rickettsia do grupo das febres maculosas. Os resultados sorológicos confirmaram a dificuldade no diagnóstico diferencial de pacientes com sintomas de doenças rickettsiais.

Palavras-chaves: Rickettsiose. Febre Maculosa. Rickettsia rickettsii. Rickettsia typhi. Rickettsia felis.

The pathogenic rickettsiae are a group of obligately intracellular bacteria responsible for a variety of human diseases. Rickettsia rickettsii causes the rickettsial disease with the highest case fatality ratio currently in Brazil ${ }^{2}$ and is transmitted by the tick Amblyomma cajennense ${ }^{3}$. This disease called Brazilian spotted fever (BSF) was first described in Brazil by Piza as a disease equivalent to Rocky Mountain spotted fever in the United States ${ }^{4}$. In Brazil BSF is known to occur in the States of Minas Gerais, São Paulo, Rio de Janeiro, Espírito Santo and Bahia ${ }^{2}$. Rickettsia typhi associated with rats and fleas has also been described in several publications ${ }^{2}$. Recent data showing the presence of antibodies to Rickettsia felis in sera from patients with fever and rash in Brazil and $R$. felis DNA in the serum of one patient indicate that $R$. felis is a new Rickettsial disease in this Country ${ }^{5}$. We report cases of spotted fever rickettsiosis in Coronel Fabriciano Municipality in Minas Gerais State, Brazil.

\footnotetext{
1. Departamento de Nutrição Clínica e Social da Universidade Federal de Ouro Preto, Ouro Preto, MG, Brazil. 2. Fundação Ezequiel Dias, Belo Horizonte, MG, Brazil. 3. Departamento de Bioquímica e Biologia Molecular da Universidade Federal de Viçosa, Viçosa, MG, Brazil. 4. Diretoria Regional de Saúde de Coronel Fabriciano, MG, Brazil. 5. Department of Pathology, World Health Organization Collaborating Center for Tropical Diseases, University of Texas Medical Branch, Galveston, TX, USA.

Address to: Dr. Márcio Galvão. Dept ${ }^{\circ}$ de Nutrição Clínica e Social, Escola de Nutrição, Universidade Federal de Ouro Preto, Campus Morro do Cruzeiro, 34.500-000, Ouro Preto, MG, Brazil.

Tel: $55313559-1838$, Fax: $55313559-1329$

e-mail:mgalvao@enut.ufop.br

Recebido para publicação em 20/6/2001

Aceito em 6/6/2003
} 


\section{MATERIAL AND METHODS}

The cases occurred in May and June of 2000. Twenty one suspected cases presenting with fever and skin rash were notified in Coronel Fabriciano Municipality (Figure 1) during this period. The majority of the cases came from a periurban area with rural characteristics named Pedreira. Among these 21 suspected cases, two children (12 and 15 years) died. They were brothers who lived in the same house. The first one to become ill was 12 years old and during the course of his disease presented fever, nausea, vomiting, diarrhea, abdominal pain, headache, myalgia and edema. Terminally he developed renal failure and stupor. The second fatal case developed fever, rash, nausea, vomiting, diarrhea, abdominal pain, headache, myalgia, jaundice and renal failure. Both cases reported a tick bite.
The sera of 21 patients with fever and rash were tested by indirect immunofluorescence assay (IFA) ${ }^{1}$ for the presence of antibodies reactive with $R$. rickettsii, $R$. typhi and Ehrlichia chaffeensis. A necropsy was performed on the second fatal case with collection of tissue samples of skin, brain, stomach, liver, spleen, and kidneys. These materials were fixed in neutralbuffered formalin and shipped to the Rickettsial and Ehrlichial Diseases Research Laboratory, Department of Pathology, University of Texas Medical Branch (UTMB) at Galveston, USA. Immunohistochemical examination for spotted fever rickettsiae was performed as described previously ${ }^{6}$. DNA was extracted from the same material and evaluated by PCR amplification of the Rickettsia 17 kDa gene ${ }^{7}$.

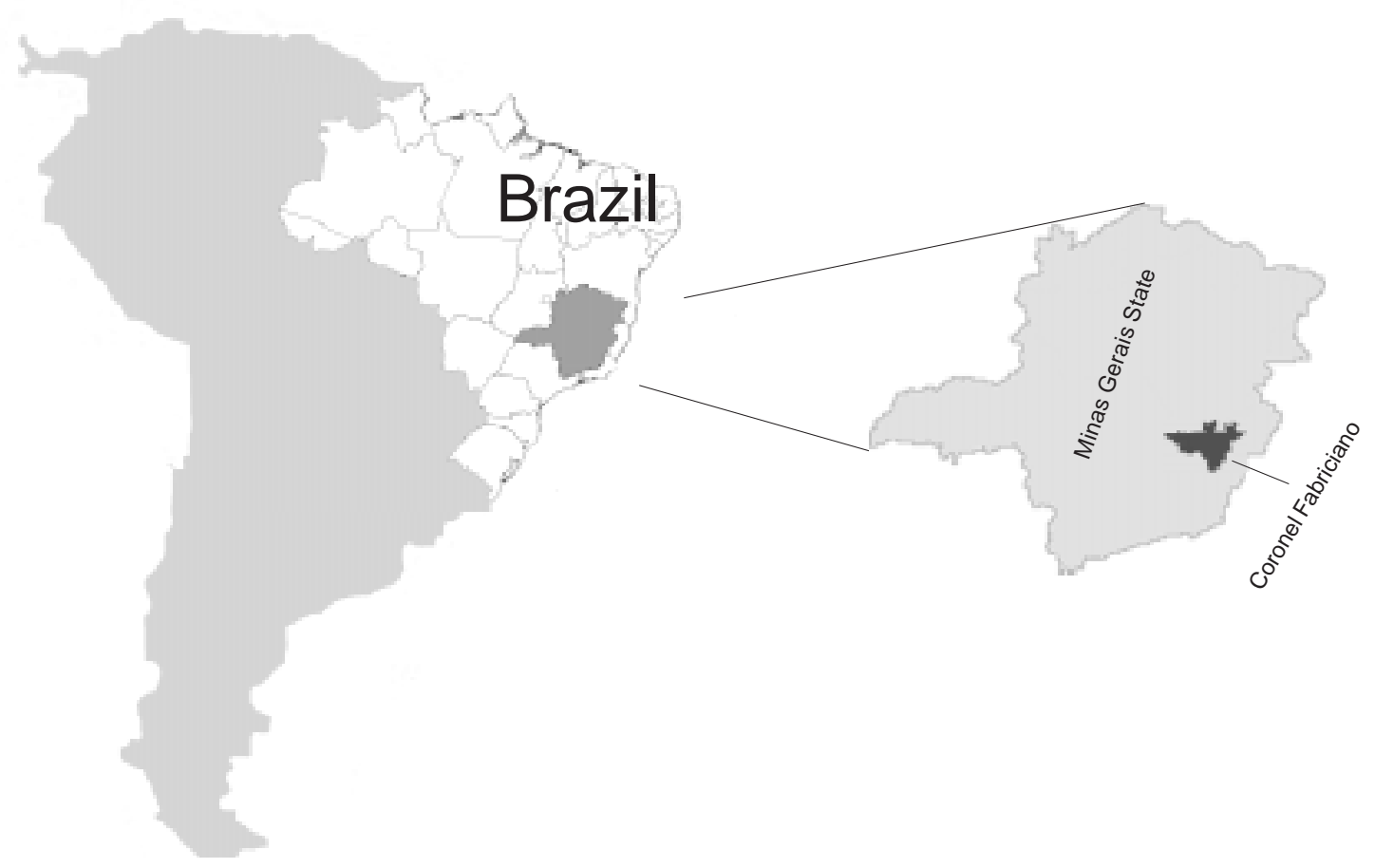

Figure 1 - South America with localization of Minas Gerais State and Coronel Fabriciano Municipality.

\section{RESULTS}

Immunohistochemical evaluation of the necropsy materials utilizing an IgM monoclonal antibody against an LPS epitope specific for Rickettsia of the spotted fever group demonstrated intraendothelial rickettsiae in the second fatal case (patient JFM). PCR performed on the necropsy materials were not conclusive, presumably owing to the use of formalin, which damages DNA.

Among the suspected cases, four had antibodies to $R$. rickettsii by IFA with a titer of 1:64 (Table 1). None had antibodies to $R$. typhi, $R$. felis or $E$. chaffeensis as determined by IFA at a dilution of 1:64.
Table 1- Seroreactivity to Rickettsia rickettsii by IFA in sera from Coronel Fabriciano Municipality - 2000, Brazil.

\begin{tabular}{lr}
\hline Identification & IFA (Titer 1:64) \\
\hline DBS (first sample) & $1: 64$ \\
DBS (second sample) & $1: 64$ \\
JFM $^{*}$ & $1: 64$ \\
JLOS & $1: 64$ \\
TRFG & $1: 64$ \\
\hline
\end{tabular}

Note: * 15 -year-old boy who died. 


\section{DISCUSSION}

The serologic results demonstrated that it was possible to suspect a diagnosis of spotted fever rickettsiosis in only four cases. They were not capable of confirming spotted fever rickettsiosis or even of identifying the species of Rickettsia involved in these cases, as there is broad cross-reactivity between spotted fever group rickettsiae. Among these cases was that of a 15-year-old boy whose diagnosis of spotted fever rickettsiosis was confirmed by immunohistochemical tests on necropsy material.
These results demonstrate clearly the difficulty in the differential diagnosis among the various rickettsial diseases and between rickettsial diseases and other non-rickettsial diseases with fever and rash, such as dengue fever. The contribution of molecular biology and good surveillance can help to elucidate the microbial species of rickettsiae involved in many cases of unrecognized fever and deaths due to Rickettsia in Brazil.

\section{REFERENCES}

1. Center for Diseases Control. Division of Viral and Rickettsial Diseases. Indirect fluorescent antibody technique for the detection of rickettsial antibodies. Atlanta, National Center for Infectious Diseases, USA.

2. Galvão MAM. A febre maculosa em Minas Gerais: Um estudo sobre a distribuição da doença no Estado e seu comportamento em área de foco peri-urbano. Tese de Doutorado, Universidade Federal de Minas Gerais, Belo Horizonte, MG, 1996.

3. Monteiro JL, Fonseca F. Typho endêmico de S. Paulo. XI. Novas experiências sobre a transmissão experimental por carrapatos (Boophilus microplus e Amblyomma cajennense). Memórias do Instituto Butantan, São Paulo 10:33-50, 1932.

4. Piza JT. Considerações epidemiológicas e clínicas sobre o Tifo Exantemático de São Paulo. In: Piza JT, Meyer JR, Salles-
Gomes L. (eds) Tifo Exantemático de São Paulo. Sociedade Impressora Paulista, São Paulo, p.11-119, 1932.

5. Raoult D, La Scola B, Enea M, Fournier PE, Roux V, Fenollar F, Galvão MAM, Lamballerie X. A flea-associated rickettsia pathogenic for humans. Emerging Infectious Diseases 7:73$81,2001$.

6. Walker DH, Hudnall SD, Szaniawski WK, Feng HM. Monoclonal antibody-based immunohistochemical diagnosis of rickettsialpox: The macrophage is the principal target. Modern Pathology 12:529-533, 1999.

7. Webb L, Carl M, Malloy DC, Dasch GA, Azad AF. Detection of murine typhus infection in fleas by using the polymerase chain reaction. Journal of Clinical Microbiology 28:530-534, 1990. 